\title{
Modification of Al-11\% Si Alloy with Cl - Based Modifier
}

\section{Tomasz Lipiński}

University of Warmia and Mazury in Olsztyn, The Faculty of Technical Sciences Department of Material and Machine Technology, St: Oczapowskiego 11, 10-957 Olsztyn, Poland. E-mail: tomekl@uwm.edu.pl

The microstructure of an unmodified hypoeutectic Al-11\%Si alloy comprises large primary $\alpha$ phase dendrites, eutectic $\beta$ phase crystals and eutectic $\alpha$ phase. This composition is responsible for the alloy's low strength parameters, and it limits the extent of practical applications. The mechanical properties of hypoeutectic silumins can be improved through chemical modification as well as traditional or technological processing. Modification improves the mechanical properties of alloys through grain refinement. This study presents the results of modification of Al-11\% Si alloy with chlorine base modifier $\left(\mathrm{NaCl}+\mathrm{CaCl}+\mathrm{SrCl}_{2}\right)$. The influence of the analyzed modifiers on the mechanical properties (tensile strength, elongation and Brinell hardness) of the processed alloy was presented in graphs. The modification of a hypoeutectic Al-11\% Si alloy improved the alloy's properties. The results of the tests indicate that the mechanical properties of the modified alloy are determined by differences compositions modifiers which are introduced to the alloy.

Keywords: Al-Si alloys, silumin, mechanical properties, modification, $\mathrm{Cl}$

\section{References}

[1] MICHNA, S., LUKAC, I., OCENASEK, V., KORENY, R., DRAPALA, J., SCHNEIDER, H., MISKUFOVA, A. (2005). Encyclopaedia of aluminium, Adin s.r.o. Presov (in Czech).

[2] MONDELFO, L.F. (1978). Aluminium alloys: Structure and Properties, London, Butterworth.

[3] CUPRYŚ, R., MAJOR, B., WOŁCZYŃSKI, W. (2000). Transition of Flake into Fibre Structure in Eutectic AlSi. In: Materials Science Forum Vol. 329-330, pp. 161-166.

[4] PACZ, A. (1921). US Patent, No. GB158827.

[5] ZIHALOVA, M., BOLIBRUCHOVA, D. (2014). Vanadium and Chromium Impact to Microstructure of AlSi10MgMn Alloy with Elevated Iron Content. In: Manufacturing Technology, Vol. 14, No. 3, pp. 498 - 502.

[6] RICHTÁRECH, L., BOLIBRUCHOVÁ, D. (2014). Effect of Selected Elements on the Microstructure of Secondary Al-Si Alloys. In: Manufacturing Technology, Vol. 14, No. 3, pp. 431 - 437.

[7] LIPIŃSKI, T., SZABRACKI, P. (2015). Mechanical Properties of AlSi9Mg Alloy with a Sodium Modifier. In: Solid State Phenomena Vol. 223, pp 78-86. TTP Switzerland.

[8] NÁPRSTKOVÁ, N., CAIS, J., SVOBODOVÁ, J. (2013). The Effect of Modification by Strontium of the AlSi7Mg0.3 Alloy on the Surface Roughness. In: Manufacturing Technology, Vol. 13, No. 3, pp. 380 - 384.

[9] YUYING, W., XIANGFA, L., XIUFANG, B. (2007). Effect of boron on the microstructure of near-eutectic AlSi alloys. In: Materials Characterization No. 58, pp. 205-209.

[10]Lipiński, T. (2011). Use Properties of the AlSi9Mg Alloy with Exothermical Modifier. In: Manufacturing Technology Vol.11, No. 11, pp. 44-49.

[11]LIPIŃSKI, T. (2008). Modification of the Al-Si Alloys with the use of a Homogenous Modifiers. In: Archives of Metallurgy and Materials, Vol. 53, Issue 1, pp. 193-197.

[12] WOŁCZYŃSKI, W., CUPRYŚ, R. (1999). The analysis of the influence of the Gibbs free energy onto the lamellarod transition in Al-Si alloy. In: Archives of Metallurgy vol. 44, No. 3, pp. 338-353.

[13]NOVÁ, I., MACHUTA, J. (2013). Squeeze casting results of aluminium alloys. In: Manufacturing Technology, Vol. 13, No. 1, pp. 73-79.

[14] WOŁCZYŃSKI, W., GUZIK, E., WAJDA, W., JĘDRZEJCZYK, D., KANIA, B., KOSTRZEWA, M. (2012). CET in Solidifying Roll - Thermal Gradient Field Analysis. In: Archives of Metallurgy and Materials No. 57, pp. 105-117.

[15]NÁPRSTKOVÁ, N., SVOBODOVÁ, J., CAIS, J. (2013). Influence of strontium in AlSi7Mg0.3 alloy on the tool wear. In: Manufacturing Technology, Vol. 13, No. 3, pp. $368-373$. 
[16]LIAO, H.C., SUN, Y., SUN, G.X. (2002). Correlation between mechanical properties and amount of dendritic Al phase in as-cast near-eutectic $\mathrm{Al}-11.6 \% \mathrm{Si}$ alloys modified with strontium. In: Material Sciences Engineering No. A 335, pp. 62-66.

[17]MAJOR, J.F., RUTTER, J.W. (1989).Effect of strontium and phosphorus on solid/liquid interface of Al-Si eutectic. In: Material Sciences Technology No. 5, pp. 645.

[18]BASAVAKUMAR, K.G., MUKUNDA, P.G., CHAKRABORTY, M. (2008). Influence of grain refinement and modification on microstructure and mechanical properties of Al-7Si cast alloys. In: Materials Characterization 59, pp. 283-289.

[19]PEZDA, J. (2007). Continous modification of AK11 silumin with multicomponent salt on base of NaCl. In: $A r-$ chives of Metallurgy and Materials No. 4, pp. 151-154.

Paper number: M2015101

Copyright $\odot$ 2015. Published by Manufacturing Technology. All rights reserved. 